Kelola

Jurnal Manajemen Pendidikan

Magister Manajemen Pendidikan

ISSN 2443-0544

FKIP Universitas Kristen Satya Wacana

Volume: 3, No. 1, Januari-Juni 2016

jurnalkelola@gmail.com

Halaman: 131-147

\title{
PENGEMBANGAN MODEL DIKLAT GURU SOSIOLOGI SMA TENTANG STRATEGI PEMBELAJARAN DISCOVERY-INQUIRY BERBANTUAN CD INTERAKTIF \\ Oleh:
}

\author{
Setyani Budi Rahayu \\ Alumni Program Pascasarjana Magister Manajemen Pendidikan \\ FKIP-Universitas Kristen Satya Wacana \\ setyani_33@yahoo.com
}

\begin{abstract}
This research development aimed to develop an education and training model for sociology teachers about inquiry discovery learning aided CD interactive. The steps taken were recognized the potential and problems, formulating design, construct an education and training model and the toolkits, experts test and product revison. Data collection used interview and study of document. The results of this research development indicated that the planning which was done before the education and training begun was to determine the training needs by analyzing the needs of the organization, set the goal of training, composed training programs; composed preliminary and final assessment tools, composed the criteria for successful training. The implementation of education and training development model of high school teachers about learning sociology with inquiry discovery learning aided interactive $\mathrm{CD}$ emphasized on training to compose lesson plans and to make $\mathrm{CD}$ interactive learning. Monitoring and evaluation for quality assessment needed to be done by the trainees by filling the questionnaire so that the responds toward the accomplishment of training and interviewees could be known. Whereas the evaluation of the trainees could be done through tests and assignments given about making lesson plans and $\mathrm{CD}$ interactive learning.
\end{abstract}

Keywords: education and training models, sociology, discovery-inquiry, CD interactive learning

\section{Pendahuluan}

Kegiatan pembelajaran yang berlangsung di sekolah terdiri dari dua konsep yang berbeda yaitu belajar dan mengajar. Keduanya pada hakikatnya tidak dapat dipisahkan satu dengan yang lain. Belajar mengacu pada kegiatan siswa sedangkan mengajar mengacu pada kegiatan guru. Slavin dalam Anni (2004:2) menyatakan 
bahwa belajar merupakan perubahan individu yang disebabkan oleh pengalaman. Sedang mengajar menurut Sardiman (2000:47) merupakan upaya menciptakan kondisi yang kondusif untuk berlangsungnya kegiatan belajar bagi para siswa. Jadi kegiatan belajar mengajar merupakan suatu bentuk interaksi antara guru dengan siswa. Guru merupakan kunci dalam peningkatan kualitas dan mereka berada di titik sentral dari titik reformasi pendidikan. Diharapkan guru mampu dalam merefleksikan, memperbaiki proses pembelajaran, mempunyai kompetensi (pengetahuan dasar) dan kaya terhadap metodologi dan strategi dalam proses pembelajaran ditengah-tengah perubahan jaman. Salah satu komptensi dasar pada mata pelajaran Sosiologi di kelas XI pada kurikulum 2013 adalah: 1) menganalisis berbagai gejala sosial dengan menggunakan konsep-konsep dasar Sosiologi untuk memahami hubungan sosial di masyarakat dan 2) Melakukan kajian, diskusi dan mengaitkan konsep-konsep dasar Sosiologi untuk mengenali berbagai gejala sosial dalam memahami hubungan sosial di masyarakat. Materi yang dikaji dalam kompetensi dasar tersebut adalah ragam gejala sosial dalam masyarakat. Konflik sosial merupakan salah satu gejala sosial di dalam mayarakat. Sesuai dengan tuntutan kurikulum 2013, diharapkan peserta didik dapat mengamati, bertanya, bereksplorasi, mengasosiasi dan mengkomunikasikan. Kelima aspek tersebut merupakan proses pembelajaran saintifik yang diharapkan dari kurikulum 2013. Hal ini dimaksudkan untuk mengurangi dominasi guru dalam pembelajaran yang cenderung transfer knowledge yang bersifat satu arah. Selama ini, pembelajaran Sosiologi yang dilakukan masih belum mengoptimalkan proses pembelajaran yang berpusat pada peserta didik. Kegiatan yang mengarah agar peserta didik melakukan eksplorasi, menjelajah dan mencari informasi dari berbagai sumber belajar dan dilanjutkan dengan proses asosiasi berupa analisis kumpulan informasi yang bermuara pada proses diskusi dan presentasi belum dilakukan secara optimal. Dengan kata lain, proses pembelajaran yang melatih peserta didik melakukan discovery-inquiry untuk mengekplorasi dan menemukan fakta, konsep, skill secara mandiri maupun terbimbing belum dilakukan secara optimal. Kegiatan-kegiatan tersebut secara ideal perlu dilakukan pada pembelajaran Sosiologi yang memiliki karakteristik berhubungan dengan masalah dan gejala di masyarakat.

Proses pengamatan terhadap gejala sosial seperti konflik sosial tidak sepenuhnya dapat dilakukan secara langsung, sehingga membutuhkan media. Metode diskoveri-inkuiri berbantuan CD interaktif merupakan alternatif yang diharapkan dapat mengubah paradigma pembelajaran berpusat pada guru menjadi pembelajaran berpusat pada siswa. Adanya pelatihan bagi guru tentang pembelajaran discovery- 
Pengembangan Model Diklat Guru Sosiologi SMA Tentang Strategi Pembelajaran Discovery-Inquiry Berbantuan CD Interaktif | Setyani Budi Rahayu inquiry berbantuan CD interaktif, dengan harapan akan dapat meningkatkan kemampuan guru melaksanakan pembelajaran. Masalah yang diteliti bagaimana pengembangan model diklat guru Sosiologi SMA tentang discovery-inquiry berbantuan CD interaktif? Tujuan secara umum yang ingin dicapai dalam penelitian ini mengembangkan model diklat guru Sosiologi SMA tentang pembelajaran discovery-inquiry berbantuan $\mathrm{CD}$ interaktif.

Banyak faktor yang menentukan kualitas pendidikan, salah satunya adalah peranan guru. Guru berhubunganlangsung dengan peserta didik, bahkan sebagai pemegang kendali pembelajaran, menentukan arah perncapaian tujuan pembelajaran. Guru juga bertugas mengelola pembelajaran peserta didik. Di tangan gurulah akan dihasilkan sumber daya manusia yang berkualtias baik secara akademis, skill, perilaku maupun sikap. Guru sebagai penentu kualitas pembelajaran yang selanjutnya akan menentukan kualitas lulusan. untuk menghasilkan peserta didik didik yang berkualtias diperlukan guru yang berkualitas, memiliki kompetensi dan dedikasi yang tinggi dalam menjalankan profesionalnya (Kunandar, 2007).

Uraian di atas menggambarkan guru memiliki peranan penting dan pemegang kunci keberhasilan mencapai tujuan kelembagaan pendidikan, karena guru adalah pengelola kegiatan belajar mengajar bagi para siswanya. Ada empat kompetensi yang perlu dikembangkan oleh guru menurut PP No 19 tahun 2005 tentang Standar Nasional Pendidikan yaitu: kompetensi pedagogik, kepribadian, sosial dan profesional. Untuk peningkatan kompetensi tersebut diperlukan pelatihan-pelatihan. Pelatihan merupakan upaya untuk meningkatkan kompetensi sumber daya manusia dan kinerja organisasi ( Mondy, 2008: 210). Sumber daya manusia yang unggul dan profesional akan diperoleh dari bentuk pelatihan. Program pengembangan SDM merupakan bagian penting dari organisasi untuk meningkatkan dan mengembangkan skill, knowledge dan ability individu sesuai dengan kebutuhan masa mendatang (Sutrisno, 2009: 64).

Pelatihan merupakan usaha mendekatkan antara kemampuan karyawan/pegawai dengan apa yang dikehendaki lembaga/organisasi. Studi yang dilakukan Tall dan Hall (Sutrisno, 2009: 72) menyimpulkan bahwa dengan mengombinasikan berbagai macam faktor seperti tehnik pelatihan yang benar, persiapan dan perencanaan yang matang, serta komitmen terhadap esensi pelatihan, maka perusahaan/ lembaga dapat mencapai manfaat kompetisi yang sangat besar di dalam era globalisasi. Menurut Sikula dalam (Sutrisno, 2009: 72), pelatihan juga sebagai suatu proses pendidikan jangka pendek memanfaatkan prosedur yang 
sistematis dan teroganisir, dimana personil non manajerial mempelajari kemampuan dan pengetahuan teknis untuk tujuan tertentu. Setiap sekolah, perlu mengadakan program pelatihan bagi guru untuk kemajuan sekolah. Sudjana (2007: 10) mengemukakan bahwa proses kegiatan dalam manajemen pelatihan mengacu kepada fungsi-fungsi manajamen. Fungsi manajemen ini dimaknai sebagai suatu proses pengarahan secara terpadu baik pikiran, kemauan, perasaan dan kecerdasan emosional untuk mewujudkan sesuatu yang telah ditetapkan sebelumnya. Proses kegiatan dalam manajemen pelatihan pada dasarnya merupakan tiga fungsi, yaitu: (a) perencanaan (planning); (b) pelaksanaan (actuating); (c) evaluasi (evaluation).

Perencanaan merupakan suatu proses kegiatan yang rasional dan sistematik dalam menetapkan keputusan, kegiatan atau langkah-langkah yang akan dilaksananakan untuk mencapai tujuan yang efektif dan efisien. Menurut (Siagian, 2007: 35), merupakan suatu kegiatan untuk menetapkan tujuan yang ingin dicapai beserta menetapkan strategi untuk mencapai tujuan tersebut, dengan kata lain perencanaan merupakan usaha konkretisasi langkah-langkah yang harus ditempuh yang dasar-dasarnya telah ditetapkan dalam strategi organisasi (Siagian, 2007: 35).

Pelaksanaan (actuating) merupakan fungsi manajemen yang utama. Fungsi actuating lebih menekankan pada kegiatan. Actuating merupakan usaha untuk menggerakkan sekelompok orang dengan terencana sehingga mencapai tujuan organisasi yang diinginkan (Terry \& Rue, 2010: 168). Pada pelatihan, actuating merupakan upaya menjadikan perencanaan menjadi kenyataan, melalui kegiatan pelatihan dalam bentuk pengarahan, transfer pengetahuan, keterampilan dan motivasi agar peserta pelatihan dapat melaksanakan kegiatan pelatihan secara optimal.

Evaluasi melalui pengawasan merupakan proses pengamatan dari seluruh kegiatan organisasi guna lebih menjamin bahwa semua pekerjaan yang sedang dilakukan sesuai dengan rencana yang telah ditentukan sebelumnya (Siagian, 2007: 125). Hal senada dikemukan oleh Terry dan Rue (2010: 10) pengawasan adalah kegiatan mengukur pelaksanaan dengan tujuan-tujuan menentukan sebab-sebab penyimpangan dan mengambil tindakan-tindakan korektif bilamana diperlukan. Dari beberapa pendapat tersebut dapat ditarik kesimpulan bahwa evaluasi melalui pengawasan merupakan suatu tindakan untuk mengontrol keseuaian antara pelaksanaan dan perencanaan serta mengambil tindakan korektif jika diperlukan.

Salah satu model pelatihan yang berkembang adalah model pelatihan siklus lima. Model pelatihan siklus lima tahap oleh Goad, dalam Nedler (1982: 11), siklus pelatihannya terdiri dari: (a) analisis kebutuhan pelatihan (analisyze to determine training reqruitmens). (b) desain pendekatan pelatihan (design the training 
Pengembangan Model Diklat Guru Sosiologi SMA Tentang Strategi Pembelajaran Discovery-Inquiry Berbantuan CD Interaktif | Setyani Budi Rahayu

approach). (c) pengembangan materi pelatihan (depelov the training materials). (d) pelaksanaan pelatihan (conduct the training) dan (e) evaluasi dan pemutakhiran pelatihan (evaluate and update the training). Pelatihan yang ditujukan bagi orang dewasa sebagai sasaran perlu memperhatikan aspek: (1) orang dewasa belajar dengan melakukan (orang dewasa ingin dilibatkan); (2) masalah dan contoh relevan dan realistis; (3) lingkungan belajar terbaik adalah lingkungan informal; (4) tidak menerapkan sistem peringkat apapun; (5) fasilitator berperan sebagai agen pembaharuan: (6) fasilitator bertanggung jawab memfasilitasi pembelajaran; (7) variasi metode yang melahirkan gairah peserta pelatihan; (8) dampak pelatihan langsung bisa dirasakan peserta (Nedler, 1982: 41). Pengembangan model pelatihan lainnya dikenal dengan istilah instructional design web model (Piscurich, 2009: 13). Tahapan model ini hampir sama dengan model Goad, yang membedakannya hanya pada hubungan timbal balik antara fase yang satu dengan yang lainnya.

Pembelajaran merupakan setiap kegiatan yang dirancang untuk membantu seseorang mempelajari suatu kemampuan dan atau nilai yang baru (Sagala, 2009:61). Kesiapan seorang guru untuk mengenal karakteristik siswa dalam pembelajaran merupakan modal utama penyampaian bahan belajar dan menjadi indikator suksesnya pelaksanaan pembelajaran. Corey (Sagala, 2009:61) memandang bahwa pembelajaran merupakan suatu proses di mana lingkungan seseorang secara sengaja dikelola untuk memungkinkan ia turut serta dalam tingkah laku tertentu dalam kondisi khusus atau menghasilkan respon terhadap situasi tertentu. Dimyati dalam Sagala (2009:62) menyatakan bahwa pembelajaran merupakan kegiatan guru secara terprogram dalam desain instruksional, untuk membuat siswa belajar secara aktif, yang menekankan pada penyediaan sumber belajar. Pembelajaran merupakan suatu sistem (Sanjaya 2008: 13), oleh sebab itu, pencapaian standar proses untuk meningkatkan kualitas pendidikan dapat dimulai dari menganalisis setiap komponen yang dapat membentuk dan mempengaruhi proses pembelajaran. Pembelajar-an merupakan suatu proses yang terdiri dari kombinasi dua aspek, yaitu: belajar tertuju kepada apa yang harus dilakukan oleh siswa, mengajar berorientasi pada apa yang harus dilakukan oleh guru sebagai pemberi pelajaran (Jihad, 2008: 11). Knirk dan Gustafson dalam Sagala (2009:64) menyatakan bahwa pembelajaran merupakan suatu proses yang sistematis melalui tahap rancangan, pelaksanaan dan evaluasi. 
Pembelajaran dengan strategi discovery-inquiry merupakan salah satu hasil pemikiran berkaitan dengan peningkatan upaya guru dalam menjalankan proses pengajaran. Strategi ini merupakan gabungan dari dua istilah yaitu discovery dan inquiry. Panggabean (2007:50) menegaskan bahwa dalam penemuan (discovery) siswa aktif menemukan sendiri hal-hal tertentu sebagai akibat pengalaman belajar yang telah didisain oleh guru. Oleh karena itu strategi seperti ini menciptakan peluang bagi para siswa untuk menjawab pertanyaan secara luas dan sekaligus mengkontribusikan dirinya dalam mengembangkan kecintaan yang mendalam terhadap pelajaran. Sedangkan dalam strategi inquiry, siswa secara mandiri menemukan dan membangun kerangka pemahamannya berdasarkan konstruksi yang ditemukannya. Menurut Marimuthu (2005:6), secara konseptual discovery-inquiry merupakan sekumpulan tingkah laku untuk mendapatkan penjelasan yang masuk akal mengenai fenomena yang sedang mereka curigai. Berdasarkan konsep tersebut, discovery-inquiry merupakan strategi mengajar yang memacu sekumpulan tingkah laku siswa agar mereka dapat mendapatkan penjelasan yang masuk akal tentang konsep, prinsip dan masalah dalam materi pembelajaran. Menurut Trowbidge (Marimuthu, 2005:10) strategi discovery-inquiry meliputi operasi penyelidikan dengan melibatkan proses eksperimen, membandingkan, menduga, menyimpulkan, mengkomunikasikan dan mengidentifikasi berbagai prinsip serta konsep melalui proses berpikir.

Menurut Sudjana (2004:154-155), strategi discovery-inquiry ini dapat dilaksanakan apabila dipenuhi syarat-syarat sebagai berikut: 1) Guru harus terampil memilih persoalan yang relevan yang diajukan kepada kelas dan sesuai dengan daya nalar siswa; 2) Guru harus terampil menumbuhkan motivasi belajar siswa dan menciptakan situasi belajar yang menyenangkan; 3) Adanya fasilitas dan sumber belajar yang cukup; 4) Adanya kebebasan siswa untuk berpendapat, berkarya dan berdiskusi; 5) Partisipasi siswa dalam setiap kegiatan belajar; 6) Guru tidak banyak campur tangan dan intervensi terhadap kegiatan siswa. Sedang menurut Bruner (Dahar, 1998:100) penekanan pada pembelajaran discovery-inquiry telah menetapkan pengaruh pembelajaran yang membimbingnya untuk menjadi seorang konstruksionis, untuk mengatur apa yang sedang dialami dalam sebuah kegiatan, bukan hanya merancang untuk menemukan dengan cara yang teratur dan pendekatan khusus, tetapi juga untuk menghindari berbagai jenis informasi yang menyamarkan data yang selayaknya disimpan.

Dalam pembelajaran discovery-inquiry ini, pertama kali siswa diberi masalah oleh guru dan diberikan bimbingan singkat untuk menemukan jawabannya. 
Pengembangan Model Diklat Guru Sosiologi SMA Tentang Strategi Pembelajaran Discovery-Inquiry Berbantuan CD Interaktif | Setyani Budi Rahayu

Diupayakan agar jawaban atau hasil akhir harus tetap ditemukan sendiri oleh siswa. Kemudian dilanjutkan dengan proses inquiry yang tahapan-tahapannya menurut Sanjaya (2008:201) sebagai berikut: 1) Orientasi. Pada tahap ini guru menjelaskan topic, tujuan dan hasil belajar. Kemudian guru menjelaskan pokok kegiatan yang dilakukan oleh siswa dan memotivasinya untuk mencapai tujuan. 2) Merumuskan masalah. Siswa merumuskan masalah sendiri, sesuai dengan konsep dan materi yang sudah jelas dan disiapkan oleh guru. 3) Mengajukan hipotesis. Siswa mengajukan jawaban sementara terhadap masalah yang mereka ajukan. 4) Mengumpulkan data, siswa mengumpulkan data untuk menjawab hipotesis dengan kemampuan berpikirnya dan menggunakan sumber-sumber yang mereka miliki. 5) Menguji hipotesis. Siswa melakukan eksperimen sebagai slah satu bentuk proses menemukan jawaban. 6) Merumuskan kesimpulan. Siswa mendeskripsikan temuan yang diperoleh berdasarkan hasil pengujian hipotesis.

Banyak ahli, terutama ahli media mengemukakan perlu adanya pemilihan media yang tepat sebagai wahana penyalur pesan dalam proses pembelajaran. Bahkan diyakini bahwa media pandang dengar (audio visual) seperti film bingkai (slide), film dan lainnya, sangat baik digunakan untuk membantu proses komunikasi di kelas. Bahkan kecenderungannya penggunaan media audio visual dalam pembelajaran lebih cepat dan mudah diterima jika dibandingkan penjelasan dengan lisan. Dengan kata lain, seberapa jauh proses komunikasi terjadi dipengaruhi oleh faktor media yang digunakan dalam komunikasi tersebut.

Media pembelajaran sudah dikenal sejak lama, bahkan sejak pendidikan formal itu ada. AECT (Association of Education and Comunication Tecnology) dalam Arsyad (2006:3) mendefinisikan media sebagai segala bentuk dan saluran yang digunakan orang untuk menyampaikan pesan atau informasi. Sedangkan Santoso (2002:3) mendefinisikan media sebagai segala sesuatu yang dapat digunakan untuk merangsang pikiran, perasaan, perhatian dan kemampuan siswa, sehingga dapat mendorong terjadinya proses belajar pada diri siswa. Sudjana (2004:112) mengungkapkan bahwa dalam situasi belajar tertentu, yaitu siswa telah memiliki disiplin belajar yang tinggi, pengalaman belajar yang cukup dan pola pikir yang matang, maka interaksi pembelajaran bisa dilakukan secara langsung antara siswa dengan media belajar. Dalam kondisi demikian, media mampu menggantikan peran guru sebagai sumber belajar. Hamalik dalam Arsyad (2006:15) mengemukakan bahwa pemakaian media pembelajaran mampu membangkitkan keinginan, minat, motivasi, dan rangsangan kegiatan belajar, bahkan membawa pengaruh psikologis 
terhadap siswa. Penggunaan media juga akan sangat membantu meningkatkan efektifitas pembelajaran.

CD interaktif merupakan kemasan media pembelajaran yang didalamnya memuat materi dan permasalahan-permasalahan sosiologi yang dilengkapi dengan tampilan, animasi dan gambaran ilustrasi. Dalam rangka penerapan pengembangan sistem pembelajaran tersebut, siswa sebagai sentral kegiatan pembelajaran (instruction), sedangkan guru aktif memberi kemudahan (fasilitas) belajar siswa dan mereka berinteraksi dengan sumber-sumber belajar yang dapat mempermudah proses belajarnya. Semua komponen sumber belajar baik : pesan, orang, bahan, peralatan, tehnik, dan latar (lingkungan) harus dimanfaatkan secara luas dan maksimal guna memecahkan masalah-masalah belajar sehingga tujuan pembelajaran dapat dicapai. Dengan kata lain, pemanfaatan sumber belajar secara luas dan maksimal tersebut adalah dalam rangka menciptakan proses pembelajaran yang lebih efektif dan efisien. Adanya perangkat komputer dengan berbagai program animasi sangat sesuai bila komputer digunakan sebagai salah satu komponen sumber pembelajaran. Konsep dan masalah materi pembelajaran yang sebelumnya hanya dituliskan dan digambarkan dalam buku, untuk saat ini bisa ditampilkan dalam bentuk tayangan melalui media audio visual dan dikemas dalam bentuk CD interaktif. Terlebih strategi pembelajaran yang digunakan terkait dengan kehidupan nyata dan teknologi, dengan bantuan komputer dan LCD, siswa bisa langsung dibawa untuk memperhatikan permasalahan dan kejadian-kejadian nyata yang terkait, bahkan mendasari munculnya suatu teori pada suatu materi pelajaran.

\section{Metode Penelitian}

Penelitian ini termasuk jenis penelitian dan pengembangan (Research \&Development) dengan lima tahapan yaitu potensi masalah, pengumpulan data, desain produk, validasi dan perbaikan produk. Lokasi penelitian dan pengembangan model pelatihan guru sosiologi tentang pembelajaran discovery-inquiry berbantuan CD interaktif adalah di Kabupaten Kendal dengan subjek guru Sosiologi SMA orang yang tersebar di SMA negeri dan swasta. Untuk mengembangkan produk dilakukan pengumpulan data dengan teknik wawancara dan studi dokumen. Hasil pengembangan model dipaparkan secara deskriptif. Model pelatihan bagi guru sosiologi tentang pembelajaran discovery-inquiry yang merupakan hasil akhir dari penelitian pengembangan ini berupa: materi pelatihan, $\mathrm{CD}$ interaktif, pedoman pelatihan baik untuk penyelenggara, narasumber, maupun untuk peserta pelatihan.

\section{Hasil Penelitian dan Pembahasan Hasil Penelitian}


Pengembangan Model Diklat Guru Sosiologi SMA Tentang Strategi Pembelajaran Discovery-Inquiry Berbantuan CD Interaktif | Setyani Budi Rahayu

Pengembangan model pelatihan guru sosiologi tentang pembelajaran discovery-inquiry berbasis CD interaktif dilakukan dengan tahapan yaitu desain model, penyusunan perangkat pelatihan, validasi produk dan perbaikan produk. Berdasarkan hasil analisis kebutuhan tentang materi tentang pembelajaran discoveryinquiry maka pelatihan ini ditetapkan untuk meningkatkan kemampuan guru sosiologi membuat perangkat pembelajaran discovery-inquiry berbasis CD interkatif dan meningkatkan kemampuan guru membuat $\mathrm{CD}$ pembelajaran interaktif. Berdasarkan tujuan inti, maka disusun program pelatihan berupa buku panduan kegiatan pelatihan, materi pelatihan dan modul pembuatan CD interaktif. Materi tersebut sebagai bahan untuk melaksanakan pelatihan dan diakhiri dengan evaluasi.

Perangkat pelatihan yang dikembangkan meliputi buku panduan pelatihan, materi pelatihan, contoh media pembelajaran interaktif. Buku panduan pelatihan berisi tentang pedoman sebagai acuan bagi penyelenggara, nara sumber dan peserta dalam proses pelatihan. Waktu pelaksanaan pelatihan direncanakan hanya dua hari. Hari pertama membahas tentang teori, hakekat pembelajaran discovery-inquiry berbantuan CD interaktif dan pembuatan RPP, sedangkan hari kedua pelatihan pembuatan CD interaktif. Panitia kegiatan pelatihan terdiri dari ketua, sekretaris, bendahara, sie acara, sie humas, sie dokumentasi dan perlengkapan.

Prosedur pelaksanaan pelatihan juga ditulis sebagai pedoman bagi penyelenggara dalam melakukan pelatihan. Adapaun prosedur yang digunakan seperti tercantum pada gambar 1 .

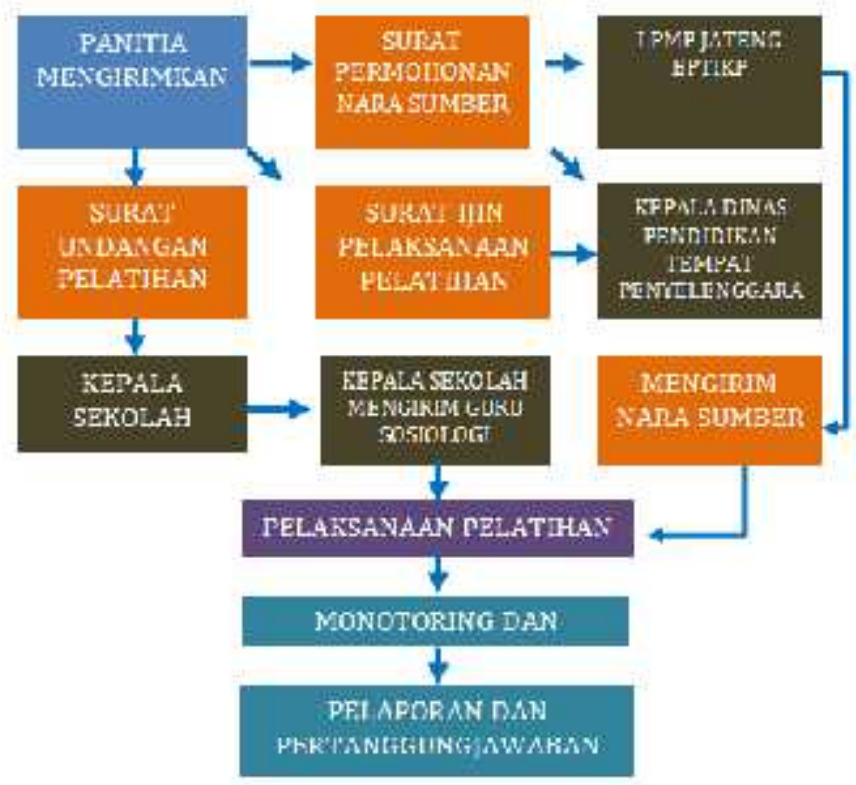


Gambar 1. Prosedur Penyelenggara Melaksanakan Pelatihan

Pelatihan yang dilaksanakan selama dua hari digunakan struktur kurikulum 16 jam pelajaran seperti tercantum pada tabel 1 .

Tabel 1.Struktur Kurikulum Pelatihan

\begin{tabular}{lll}
\hline No & \multicolumn{1}{c}{ Mata Latih } & JPL \\
\hline 1 & $\begin{array}{l}\text { Konsep Pembelajaran Discovery-inquiry berbantuan CD interaktif pada } \\
\text { mata pelajaran sosiologi }\end{array}$ & 2 \\
2 & $\begin{array}{l}\text { Pembuatan Rancangan Pelaksanaan Pembelajaran Discovery-inquiry } \\
\text { berbantuan CD interaktif pada mata pelajaran sosiologi }\end{array}$ & 2 \\
3 & Pembuatan Media Pembelajaran CD Interaktif & 12 \\
\hline & Jumlah & 16
\end{tabular}

Struktur kurikulum pelatihan ini dilaksanakan secara rinci seperti tercantum pada tabel 2 .

Tabel 2. Jadwal Kegiatan Pelatihan

Hari Pertama

\begin{tabular}{llll}
\hline No & Waktu & Materi Pelatihan & Nara sumber \\
\hline 1 & $07.00-08.00$ & Registrasi & \\
2 & $08.00-08.30$ & Pembukaan dan sambutan-sambutan & $\begin{array}{l}\text { Kepala SMA tempat } \\
\text { penyelenggara }\end{array}$ \\
3 & $08.30-08.45$ & $\begin{array}{l}\text { Coffe break } \\
\text { Konsep Pembelajaran Discovery- } \\
\text { inquiry berbantuan CD interaktif pada } \\
\text { mata pelajaran sosiologi }\end{array}$ & Widyaiswara \\
4 & $08.45-10.15$ & $\begin{array}{l}\text { Pembuatan Rancangan Pelaksanaan } \\
\text { Pembelajaran Discovery-inquiry } \\
\text { berbantuan CD interaktif pada mata } \\
\text { pelajaran sosiologi }\end{array}$ & Widyaiswara \\
5 & $10.15-12.00$ & $\begin{array}{l}\text { ISOMA } \\
\text { Pembuatan Media CD Interaktif }\end{array}$ & Ahli Media BPTIKP \\
\hline 7 & $12.00-13.00$ & Materi Pelatihan & Nara sumber \\
\hline Hari Kedua & $13.00-16.00$ & Pembuatan Media CD Interaktif & $\begin{array}{l}\text { Ahli Media } \\
\text { BPTIKP }\end{array}$ \\
\hline No & Waktu & ISOMA & Ahli Media \\
\hline 1 & $08.00-12.00$ & Pembuatan Media CD Interaktif & \\
2 & $12.00-13.00$ & &
\end{tabular}

Buku panduan pelatihan bagi nara sumber relatif sama dengan buku panduan untuk penyelenggara hanya isinya ada yang dikurangi yaitu rencana anggaran. Perbedaan lainnya terletak pada bagian prosedur dan tata tertib bagi pelatih. 
Pengembangan Model Diklat Guru Sosiologi SMA Tentang Strategi Pembelajaran Discovery-Inquiry Berbantuan CD Interaktif | Setyani Budi Rahayu

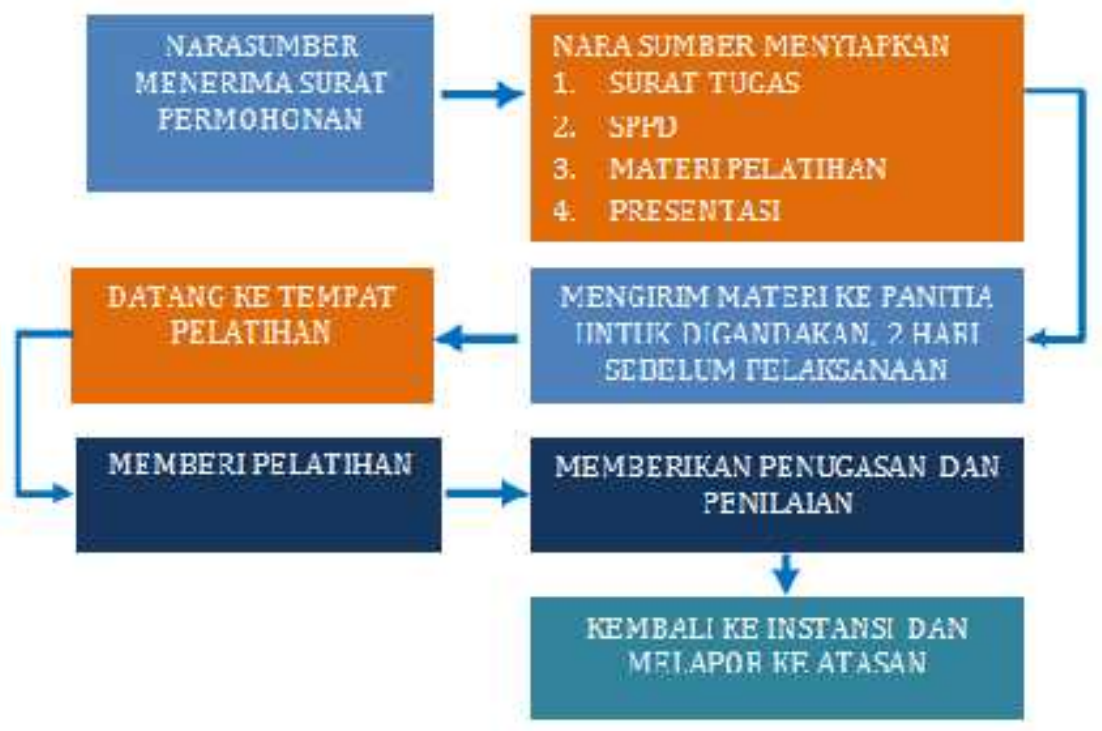

Gambar 2. Prosedur Narasumber Melaksanakan Pelatihan

Buku panduan bagi peserta pelatihan juga relatif sama dengan buku panduan untuk nara sumber, yang membedakan adalah pada prosedurnya.

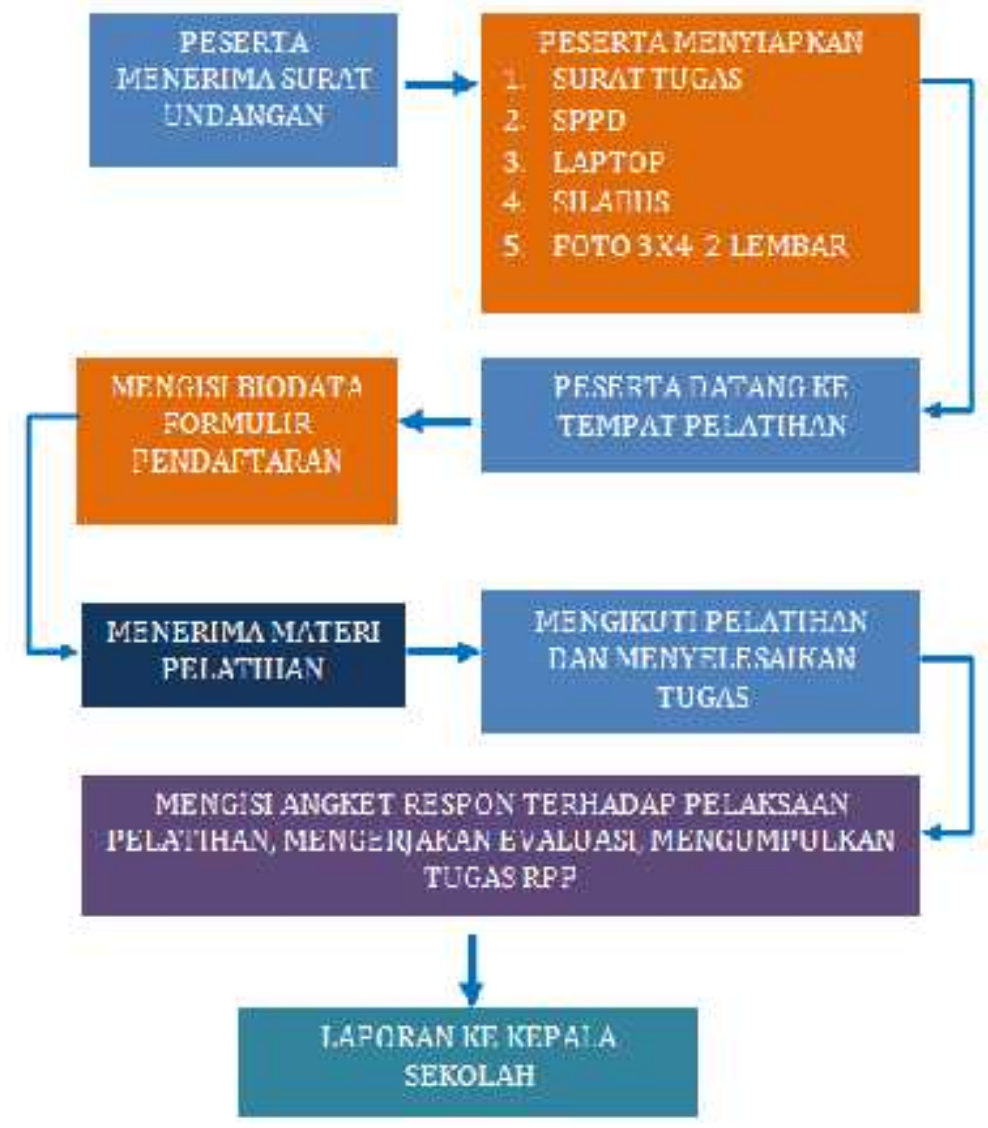


Gambar 3. Prosedur Pelatihan untuk Peserta Pelatihan

Untuk mengetahui ketercapaian pelaksanaan pelatihan maka dibagikan angket untuk memberikan respon kepada penyelenggara dan narasumber, sedangkan untuk mengetahui hasil pelatihan bagi peserta didik dilakukan tes dan pengumpulan hasil penugasan berupa RPP

Buku materi pelatihan digunakan sebagai sumber belajar dalam mengikuti pelatihan. Buku materi pelatihan berisi tentang tiga bab. Bab I berisi tentang latar belakang dan tujuan. Bab II berisi materi tentang pembelajaran discovery-inquiry berbantuan CD Pembelajaran Interaktif. Dalam bab ini dituliskan tentang konsep dasar pembelajaran discovery inquiry, pemanfaatan CD Pembelajaran Interaktif dan aplikasi Pembelajaran Discovery-inquiry Berbasis CD Interaktif pada Mata Pelajaran Sosiologi. Bab III, penutup.

Produk yang dikembangkan berupa pedoman pelatihan pembelajaran discovery-inquiry berbantuan CD interaktif dan materi pelatihan divalidasi oleh 3 validator. Rata-rata hasil validasi ketiga validator mencapai 4,35 pada interval 4,35,0 dalam kategori sangat tinggi. Hal ini menunjukkan bahwa pedoman pelatihan yang dikembangkan sudah tergolong sangat valid. Rata-rata hasil validasi keempat validator terhadap pengembangan produk materi sebesar 4,03 pada interval 3,4-4,2 dalam kategori tinggi. Hal ini menunjukkan bahwa materi pelatihan yang dikembangkan sudah tergolong valid dengan beberapa saran.

Berdasarkan hasil validasi dan saran dari ahli, selanjutnya dilakukan revisi sehingga diperoleh model diklat guru sosiologi SMA tentang pembelajaran discovery-inquiry berbantuan CD interaktif. Model tersebut dituliskan dalam bentuk: a) Pedoman diklat bagi penyelenggara. b) Pedoman diklat bagi narasumber. c) Pedoman diklat bagi peserta diklat. d) Materi diklat tentang pembelajaran discoveryinquiry pada mata pelajaran sosiologi. e) Contoh CD interaktif sebagai pendukung materi. Kelima produk hasil pengembangan tersebut sudah direvisi berdasarkan saran dari ahli.

\section{Pembahasan}

Pelatihan yang baik dengan proses perencanaan dan prosedur yang jelas, terarah dan dilakukan evaluasi yang tepat diharapkan akan berimbas pada kesadaran bagi guru untuk melakukan proses pembelajaran dengan kualitas yang lebih baik. Pelatihan merupakan jantung dari upaya untuk meningkatkan kompetensi sumber daya manusia dan kinerja organisasi (Mondy, 2008: 210). Melalui pelatihan akan diperoleh sumber daya manusia yang unggul dan profesional diharapkan oleh banyak organisasi atau lembaga pendidikan untuk bisa bersaing dalam era globalisasi. 
Pengembangan Model Diklat Guru Sosiologi SMA Tentang Strategi Pembelajaran Discovery-Inquiry Berbantuan CD Interaktif | Setyani Budi Rahayu

Program pengembangan sumber daya manusia merupakan strating point bagi organisasi untuk meningkatkan dan mengembangkan skill, knowledge dan ability individu sesuai dengan kebutuhan masa mendatang (Sutrisno, 2009: 64).

Penelitian pengembangan ini memiliki tujuan untuk menghasilkan desain atau prosedur pelatihan bagi guru sosiologi tentang pembelajaran inkuiri berbasis budaya lokal, yang diharapkan dapat dijadikan sebagai acuan untuk melaksanakan pelatihan. Hal ini sesuai dengan tujuan pelatihan yaitu mencapai kemampuan dan keterampilan yang diperlukan dalam jabatan atau pekerjaan (Sallis, 2004: 39). Pernyataan tersebut membuktikan bahwa orang yang sudah mengikuti pelatihan akan memiliki pengetahuan dan keterampilan yang lebih baik

Atas dasar tujuan pelatihan tersebut maka dilakukan proses penyusunan program pelatihan. Program pelatihan tersebut dituangkan dalam bentuk panduan pelatihan yang terdiri dari tiga yaitu panduan bagi penyelenggara, panduan bagi pelatih dan panduan bagi peserta pelatihan. Program pelatihan juga dilengkapi materi pelatihan yang dapat dimanfaatkan oleh peserta pelatihan. Program yang disusun digunakan sebagai acuan bagi penyelenggara untuk melaksanakan pelatihan. Pada saat proses maupun akhir pelatihan dapat dilakukan monitoring dan evaluasi untuk melakukan pengukuran sehingga dapat diketahui tingkat ketercapaian pelatihan. Buku Pedoman berisi tentang latar belakang yang mengungkapkan pentingnya pelatihan dilaksanakan dan tujuan pelatihan sebagai arah bagi penyelenggara, pelatih dan peserta pelatihan mengikuti pelatihan. Dicantumkan pula dasar hukum sebagai acuan dasar bagi pelatihan agar pelatihan tidak menyimpang dari landasan hukum yang ada.

Nara sumber merupakan sumber daya manusia dalam pelatihan yang penting. Oleh karena itu, pemilihan nara sumber merupakan bagian yang penting dilakukan oleh penyelenggara. Kualitas pelatihan selain dipengaruhi oleh kelancaran penyelenggaraan, fasilitas yang ada dipengaruhi pula oleh kualitas nara sumber. Pengalaman, kedalaman materi, cara penyampaian, kemampuan komunikasi nara sumber dapat mempengaruhi peserta pelatihan dalam mengikuti pelatihan. Sesuai dengan karakteristik materi pelatihan yaitu tentang pembelajaran discovery-inquiry berbantuan $\mathrm{CD}$ interaktif, maka pelatihan dapat menggunakan nara sumber dari widyaiswara LPMP dan ahli media dari BPTIKP. Kedua narasumber dapat saling melengkapi, karena widyaiswara dipandang memiliki keilmuan secara teoretis secara mendalam tentang metode pembelajaran discovery-inquiry sedangkan ahli media 
dari BPTIKP dipandang memiliki pengalaman yang mendalam cara pembuatan media CD interaktif.

Unsur penting dalam pelatihan adalah pemilihan waktu yang tepat. Waktu pelatihan perlu dipertimbangkan secara baik dengan mempertimbangkan materi yang akan disampaikan. Waktu yang terlalu singkat akan berpengaruh pada kurangnya kedalaman materi yang disampaikan, namun waktu yang terlalu lama menjadi kurang efektif karena peserta akan mengalami kejenuhan. Terkait dengan materi pelatihan pembelajaran discovery-inquiry berbantuan CD interaktif, maka materi yang perlu disampaikan minimal dua hari. Hari pertama dapat membahas konsep pembelajaran discovery-inquiry berbantuan $\mathrm{CD}$ interaktif dan proses pembuatan rencana pelaksanaan pembelajarannya dan berlanjut dengan proses pembuatan CD interaktif. Hari berikutnya dilanjutkan pembuatan CD interaktif.

Penyelenggara pelatihan merupakan faktor kunci keberhasilan pelaksanaan pelatihan. Tanpa adanya panitia penyelenggara yang mampu memberikan pelayanan pelatihan secara baik, pelatihan tidak akan berlangsung dengan baik. Prosedur bagi penyelenggara perlu dituliskan dalam buku pedoman pelatihan. Melalui prosedur tersebut pihak penyelenggara akan melakukan proses perencanaan dan pelaksanaan pelatihan secara terarah. Kejelasan pembagian tugas akan mempermudah panitia penyelenggara pelatihan melakukan kinerjanya demi berlangsungnya pelaksanaan pelatihan.

Prosedur yang jelas merupakan bagian penting bagi penyelenggara melakukan semua kegiatan demi berlangsungnya pelaksanaan pelatihan. Menurut Kamil (2010), fungsi organizing merupakan ruh yang hadir mengisi di ketiga fungsi yang lainnya yaitu planning, actuating dan controlling dalam setiap action pada pelatihan, fungsi organizing merupakan command (komando) yang mensinergikan komponen dalam penyelenggaraan pelatihan, sehingga kerjasama antara sumber daya manusia yang terlibat secara aktif di dalam manajemen pelatihan mengetahui tugas dan tanggung jawabnya masing-masing. Prosedur kerja bagi penyelenggara akan mengontrol proses kerja para penyelenggara, kerjasama antara penyelenggara dengan narasumber dan peserta pelatihan. Panduan pelatihan perlu dicantumkan program pelatihan atau kurikulum pelatihan. Materi-materi apa saja yang akan disampaikan dalam pelatihan perlu ditulis secara jelas, dengan alokasi waktu dan siapa narasumbernya. Program ini sebagai acuan bagi narasumber untuk menyusun materi dan bagi peserta pelatihan sebagai arah tujuan yang akan dicapai melalui pelatihan tersebut. Materi pelatihan ditetapkan berdasarkan need assesment yang dituangkan dalam perencanaan pelatihan berupa kurikulum pelatihan, buku panduan pelatihan, 
Pengembangan Model Diklat Guru Sosiologi SMA Tentang Strategi Pembelajaran Discovery-Inquiry Berbantuan CD Interaktif | Setyani Budi Rahayu

dan materi pelatihan. Pelatihan tidak lepas dari faktor pembiayaan. Biaya merupakan faktor penting dalam pelaksanaan pelatihan karena pelaksanaan akan berjalan sesuai rencana apabila ditopang dengan dana yang memadai. Oleh karena itu pembiayaan pelatihan perlu diatur dan dikoordinasikan antara penyelenggara pelatihan, pejabat pembina profesi guru, guru dan pihak lain yang terkait. Biaya merupakan faktor penggerak berlangsungnya pelatihan. Setidaknya biaya pelatihan dirinci untuk pembiayaan trasport dan honor nara sumber, transport peserta pelatihan, konsumsi, ATK dan pelengkapan. Rincian pembiayaan yang jelas akan mempermudah bendahara penyelenggara mengatur pengeluaran yang digunakan untuk pelatihan.

Di saat proses kegiaan maupun di akhir kegiatan pelatihan, perlu dilakukan monitoring dan evaluasi atau pengawasan. Pengawasan merupakan proses pengamatan dari seluruh kegiatan organisasi guna lebih menjamin bahwa semua pekerjaan yang sedang dilakukan sesuai dengan rencana yang telah ditentukan sebelumnya (Siagian, 2007: 125). Sedangkan menurut Handoko (2008: 360) Pengawasan dapat juga berarti menetapkan standar pelaksanaan dengan tujuantujuan perencanaan, merancang sistem informasi umpan balik, membandingkan kegiatan nyata dengan standar yang telah ditetapkan sebelumnya, menetapkan dan mengukur pe-nyimpangan-penyimpangan, serta mengambil tindakan koreksi yang diperlukan untuk menjamin bahwa semua sumber daya perusahaan dipergunakan dengan cara efektif dan efisien dalam pencapaian perusahaan. Hal senada dikemukan oleh Terry dan Rue (2010: 10) pengawasan adalah kegiatan mengukur pelaksanaan dengan tujuan-tujuan menentukan sebab-sebab penyimpangan dan mengambil tindakan-tindakan korektif bilamana diperlukan.

Terkait dengan pelatihan pembelajaran discovery-inquiry berbantuan CD interaktif, maka untuk mengetahui efektivitas pelatihan dapat dilihat dari: respon peserta pelatihan terhadap penyelenggaraan dan narasumber serta kemampuan peserta pelatihan tentang pembelajaran discovery-inquiry berbantuan CD interaktif dan hasil tugas pembuatan RPP dan CD interaktif.

\section{Simpulan}

Berdasarkan kegiatan penelitian pengembangan telah dapat dihasilkan model diklat tentang pembelajaran discovery-inquiry berbantuan $\mathrm{CD}$ interaktif. Model tersebut tertuang dalam pedoman pelatihan bagi penyelenggara, narasumber, peserta pelatihan, materi pelatihan dan CD interaktif sebagai pendukung materi diklat. Agar pelaksanaan pelatihan tentang pembelajaran discovery-inquiry berbantuan $C D$ interaktif dapat terlaksana dengan baik, maka disarankan: 1) Bagi penyelenggara 
perlu menyusun perencanaan pelatihan sebelum diklat yaitu dengan berpedoman pada analisis kebutuhan pelatihan, menetapkan tujuan pelatihan dan menyusun program pelatihan. 2) Bagi penyelenggara perlu menyusun panduan pelatihan yang jelas bagi penyelenggara, narasumber dan peserta pelatihan dan materi pelatihan sebagai pedoman pelaksanaan pelatihan. 3) Bagi penyelenggara, pelaksanaan pengembangan model diklat guru SMA tentang pembelajaran discovery-inquiry berbantuan CD interaktif perlu difokuskan pada pelatihan menyusun RPP aplikasi pembelajaran dengan metode discovey inquiry berbantuan $\mathrm{CD}$ interkatif dan pembuatan CD interaktif. 4) Bagi narasumber pelatihan, perlu melakukan evaluasi pelaksanaan pengembangan model diklat guru SMA tentang pembelajaran discovery-inquiry berbantuan $\mathrm{CD}$ interaktif yang dilakukan dengan menilai kompetensi peserta pelatihan melalui tes dan penugasan pembuatan RPP serta pengumpulan tugas pembatuan $\mathrm{CD}$ interaktif. 4) Bagi penyelenggara dapat melihat kuesioner oleh peserta pelatihan sehingga dapat diketahui respon terhadap penyelenggaraan dan narasumber.

\section{DAFTAR PUSTAKA}

Anni, Catharina Tri dkk. 2004. Psikologi Belajar. Semarang: UPT MKK UNNES. Arsyad, Azhar. 2006. Media Pembelajaran. Jakarta: PT Raja Grafindo Persada. Dahar, R. W. 1998. Teori-Teori Belajar. Jakarta: Erlangga.

Dharma, S. 2009. Arah Kebijakan Peningkatan Mutu Pendidik dan Tenaga Kependidikan. Makalah Seminar Nasional Dies Natals UNNES-ke 44. Pascasarjana UNNES.

Dimyati dan Mudjiono. 2006. Belajar dan Pembelajaran. Jakarta: Rineka Cipta. Grafindo Persada.

Hamalik, Oemar. 2008. Proses Belajar Mengajar. Bandung: Bumi Aksara.

Jihad, Asep dan Abdul Haris. 2008. Evaluasi Pembelajaran. Yogyjakarta: Multi Pressindo.

Kamil, Mustofo. 2010. Model Pendidikan dan pelatihan. Bandung: Alfabeta.

Kunandar. 2007. Guru Profesional, Implementasi Kurikulum Tingkat Satuan Pendidikan (KTSP) dan Persiapan Menghadapi Sertifikasi Guru. Jakarta: PT. Raja Grafindo Persada

Marimuthu, T. 2005. An Insight into Constrctivism and Discovery-inquiry in the Teaching of Science by Secondary School Trainee Teachers during Practicum http://www.ipbl.edu.my/inter/ penyelidikan/seminarpapers/ 2005/thangaveloMPSAH.pdf. (10 Pebruari 2014).

Mondy, Wayne R. 2008. Manajemen Sumber daya manusia: Edisi Kesepuluh. Terjemahan. Jakarta: Erlangga

Mujiman, Haris. 2011. Manajemen Pelatihan Berbasis Belajar mandiri. Yogyakarta: Pustaka Pelajar. 
Pengembangan Model Diklat Guru Sosiologi SMA Tentang Strategi Pembelajaran Discovery-Inquiry Berbantuan CD Interaktif | Setyani Budi Rahayu

Mulyasa, E. 2005. Menjadi Guru Profesional (Menciptakan Pembelajaran Kreatif dan Menyenangkan). Bandung: Remaja Rosdakarya.

Nadler, L. 1982. Designing Training Program: The Critical Events Model. Philiphines: Addison-Wesley Publishing Company, Inc.

Panggabean, Y, dkk. 2007. Strategi, Model dan Evaluasi Pembelajaran Kurikulum 2006. Bandung: Bina Media

Pidarta, Made .1997.Landasan Kependidikan Stimulus Ilmu Pendidikan Bercorak Indonesia . Jakarta : Rineka Cipta.

Piskurich, G. M. 2009. Rapid Training Development: Development Training Courses Fast and Right. San Fransisco: John Wuley and Sons Inc.

Sagala, Syaiful. 2009. Konsep dan Makna Pembelajaran. Bandung : Alfabeta.

Sanjaya, Wina. 2008. Strategi Pembelajaran, Berorientasi Standar Proses Pendidikan. Jakarta: Kencana Prenada Media Group.

Santoso, S. 2003. Buku latihan SPSS Statistik Multivariat. Cetakan kedua. Jakarta: PT Gramedia.

Sardiman, A.M. 2000. Interaksi Dan Motivasi Belajar-Mengajar. Jakarta: Raja

Siagian, Sondang. 2007. Fungsi-fungsi Manajerial. Jakarta: PT. Bumi Aksara

Solihatin, Etin dan Raharjo. 2008. Cooperative Learning Analisis Model Pembelajaran IPS. Jakarta : Prenada Media

Sudjana, Nana. 2004. Metoda dan Teknik Pembelajaran Partisipatif. Bandung: Sinar Baru Algesindo.

Sugiyono.2012. Metode Penelitian Kombinasi (Mixed Methods). Bandung: Alfabeta

Suparman, M. Atwi. 2001. Disain Instruksional. Jakarta: Proyek Pengembangan Universitas Terbuka Direktorat Jenderal Pendidikan Tinggi Departemen Pendidikan Nasional.

Sutrisno, Edi. 2009. Manajemen Sumber Daya Manusia. Jakarta: Kencana Prenada Media Group.

Terry, G.R. dan Rue, L.W. 2009. Dasar-dasar Manajemen. Jakarta: PT. Bumi Aksara

Terry, G.R. dan Rue, L.W. 2010. Principles of management. Edisi Bahasa Indonesia. Penerjemah G.A. Ticoalu. Jakarta: Bumi Aksara.

Uno, Hamzah B. 2007. Model Pembelajaran Menciptakan Proses Belajar Mengajar yang Kreatif dan Efektif. Jakarta: Bumi Aksara. 